\title{
Resistance to Sweetpotato Chlorotic Stunt Virus and Sweetpotato Feathery Mottle Virus Is Mediated by Two Separate Recessive Genes in Sweetpotato
}

\author{
R.O.M. Mwanga ${ }^{1}$ \\ Department of Horticultural Science, North Carolina State University, 201 Kilgore Hall, Box 7609, \\ Raleigh, NC 27695-7609
}

\author{
A. Kriegner \\ Austrian Research Centers, Biotechnology Unit, A-2444 Seibersdorf, Austria
}

J.C. Cervantes-Flores

Department of Horticultural Science, North Carolina State University, 201 Kilgore Hall, Box 7609, Raleigh, NC 27695-7609

D.P. Zhang

International Potato Center (CIP), Apartado 1558, Lima 12, Peru

J.W. Moyer
Department of Plant Pathology, North Carolina State University, 1414 Gardner Hall, Box 7616, Raleigh,
NC 27695-7616

\section{G.C. Yencho ${ }^{2}$}

Department of Horticultural Science, North Carolina State University, Vernon G. James Research and Extension Center, 207 Research Station Road, Plymouth, NC 27962

\begin{abstract}
ADDITIONAL INDEX wORDS. Ipomoea batatas, sweetpotato virus disease, linkage analysis, ELISA, whitefly, aphids
Abstract. When sweetpotato chlorotic stunt crinivirus (SPCSV) and sweetpotato feathery mottle potyvirus (SPFMV) infect sweetpotato [Ipomoea batatas (L.) Lam.], they interact synergistically and cause sweetpotato virus disease (SPVD), a major constraint to food productivity in east Africa. The genetic basis of resistance to these diseases was investigated in 15 sweetpotato diallel families (1352 genotypes) in Uganda, and in two families of the same diallel at the International Potato Center (CIP), Lima, Peru. Graft inoculation with SPCSV and SPFMV resulted in severe SPVD symptoms in all the families in Uganda. The distribution of SPVD scores was skewed toward highly susceptible categories (SPVD scores 4 and 5), eliminating almost all the resistant genotypes (scores 1 and 2). Likewise, when two promising diallel families ('Tanzania' $x$ 'Bikilamaliya' and 'Tanzania' $x$ 'Wagabolige') were graft inoculated with SPCSV and SPFMV at CIP, severe SPVD was observed in most of the progenies. Individual inoculation of these two families with SPCSV or SPFMV, and Mendelian segregation analysis for resistant vs. Susceptible categories led us to hypothesize that resistance to SPCSV and SPFMV was conditioned by two separate recessive genes inherited in a hexasomic or tetradisomic manner. Subsequent molecular marker studies yielded two genetic markers associated with resistance to SPCSV and SPFMV. The AFLP and RAPD markers linked to SPCSV and SPFMV resistance explained 70\% and $72 \%$ of the variation in resistance, respectively. We propose naming these genes as spcsv1 and spfmv1. Our results also suggest that, in the presence of both of these viruses, additional genes mediate oligogenic or multigenic horizontal (quantitative) effects in the progenies studied for resistance to SPVD.
\end{abstract}

Sweetpotato (Ipomoea batatas (L.) Lam.), with a mean annual production of 132 million tons between 1991-2000, ranks among the top 10 food crops globally (FAO, 2000). Sweetpotatoes are grown in $>100$ countries, but developing countries account for over $98 \%$ of the total production (Gregory et al., 1990; Horton, 1988). Sweetpotatoes are a good source of carbohydrates, and

Received for publication 13 Nov. 2001. Accepted for publication 3 June 2002. This research was part of the McKnight Foundation Collaborative Crop Research Program and was jointly funded by the McKnight Foundation (Minnesota); the National Agricultural Research Organization (NARO), Uganda; and the Austrian Research Centers, Seibersdorf, Austria. We thank Luis Salazar and Segundo Fuentes for providing SPFMV and SPCSV inoculum and technical advice for virus resistance evaluation at CIP. We also thank Doris Carbajulca and Geneveva Rossell for helping with the AFLP analysis.

${ }^{1}$ Current address: National Agricultural Research Organization (NARO), Namulonge Agricultural and Animal Production Research Institute (NAARI), P.O. Box 7084, Kampala, Uganda.

${ }^{2}$ Corresponding author; e-mail Craig_Yencho@ncsu.edu. both sweetpotato storage roots and foliage are nutritious foods (Food and Nutrition Board, 1980; Watt and Merrill, 1975; Woolfe, 1992). Orange fleshed sweetpotatoes are particularly nutritious, ranking highest in nutrient content of all vegetables for vitamins $\mathrm{A}$ and $\mathrm{C}$, folate, iron, copper, calcium, and fiber, and they are an excellent source of the carotenoid, $\beta$-carotene, a vitamin A precursor (Woolfe, 1992).

Sweetpotato has enormous potential to contribute to the alleviation of widespread food shortages and vitamin A malnutrition common to many developing countries in sub-Saharan Africa (SSA). However, sweetpotato virus disease (SPVD) is a major constraint to increases in sweetpotato productivity in this region. SPVD in SSA is widespread (Hahn et al., 1981; Schaefers and Terry, 1976; Wisler et al., 1998) and causes up to $98 \%$ yield loss (Gibson et al., 1998; Karyeija et al., 1998). The disease is caused by the dual infection and synergistic interaction of sweetpotato feathery mottle potyvirus (SPFMV) and sweetpotato chlorotic 
Table 1. Expected phenotypic ratios (resistant: susceptible) in testcrosses involving virus resistance genes according to four cytological hypotheses, assuming sweetpotato genomic constitution is $R_{1} R_{1} R_{2} R_{2} R_{2} R_{2}(R=$ dominant, $r=$ recessive $)$. Tetradisomic and tetrasomic inheritance exhibit similar phenotypic ratios (Jones, 1967). Segregation ratios verified by Kumagai et al. (1990).

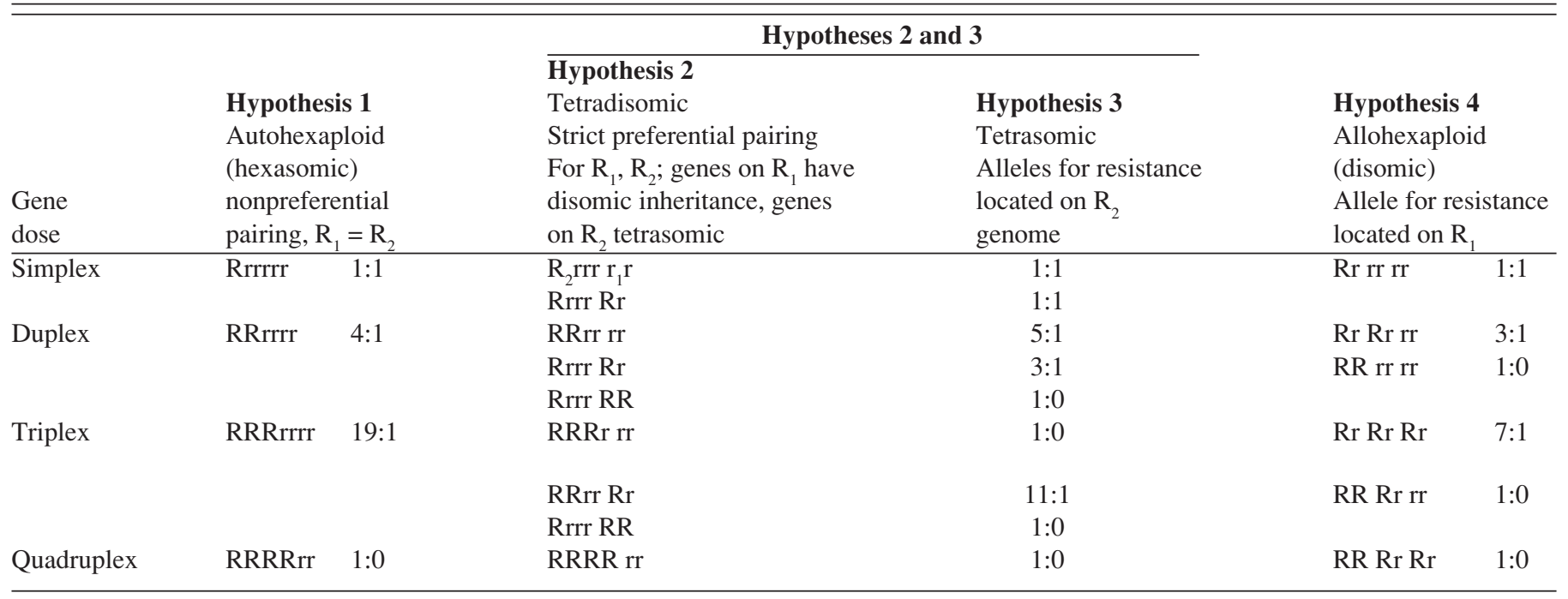

stunt crinivirus (SPCSV) (Cohen et al., 1992; Hoyer et al., 1996; Karyeija et al., 2000; Schaefers and Terry, 1976). SPFMV is transmitted in a nonpersistent, noncirculative manner by aphids (Myzuspersicae (Sulzer), Aphis gossypii Glover and A.craccivora Koch) (Stubbs and McLean, 1958), while SPCSV is transmitted semi-persistently by the whitefly [Bemesia tabaci (Gennadius)] (Cohen et al., 1992; Schaefers and Terry, 1976).

Although SPVD is devastating, only a couple of studies of its inheritance have been conducted (Hahn et al., 1981; Ngeve and Bouwkamp, 1991). Genetic analysis of inheritance of SPVD and other traits in sweetpotato has been problematic because sweetpotato is a highly heterozygous hexaploid $(x=15,2 n=90)$ (Jones, 1967; Magoon et al., 1970; Shiotani, 1988; Ting and Kehr, 1953; Ukoskit and Thompson, 1997) with complex segregation ratios (Jones, 1967; Kumagai et al., 1990; Poole, 1955). In addition to having a very complex genome, sweetpotato has many sporophytic self- and cross-incompatibilities (Jones, 1967; Martin, 1965, 1970; Nakanishi and Kobayashi, 1979; Nishiyama et al., 1975), and many genotypes fail to bloom and set seed (Jones, 1967; Magoon et al., 1970; Poole 1955). In most crop species, backcross, testcross, or $F_{2}$ populations are usually used to study the segregation of gametes from a heterozygous individual. However, the regular use of backcross or testcross populations for genetic analysis of sweetpotato is impractical due to the factors mentioned above and the strong inbreeding depression observed in backcrosses (Nissila et al., 1999). As a consequence, $F_{1}$ progeny resulting from crosses between clones, which result in high levels of segregation, are used to study the inheritance of traits in sweetpotatoes (Jones, 1977; Jones, et al., 1976a, 1976b; Thompson, et al., 1994).

Much attention has been given to the potential applications of DNA markers to improve plant breeding efficiency. These technologies provide two new opportunities for improving sweetpotato virus resistance. First, they provide a basis for accelerated breeding through early selection of traits, and second, they may enable more efficient selection of parents for subsequent crosses. DNAbased markers such as randomly amplified polymorphic DNA (RAPD), restriction fragment length polymorphisms (RFLP), microsatellites or simple sequence length polymorphisms (SSLP), and amplified fragment length polymorphisms (AFLP) have been associated with simply inherited and complex traits (quantitative trait loci, QTL) in oilseed rape. (Brassica napus L.) (Pongam et al., 1998), potato (Solanum tuberosum L.) (Barone et al., 1990; Bendahmane et al. 1997; Bradshaw et al., 1998; De Jong et al., 1997; Jacobs et al. 1995) and many other polyploid crops (Jin et al., 1998).

In this study, we report on 1) a series of genetic studies focused on examining the inheritance of resistance to SPCSV, SPFMV and SPVD; 2) the development of a preliminary linkage map of sweetpotato; and 3) the identification of AFLP and RAPD markers linked to genes conferring resistance to SPCSV and SPFMV on this map. AFLPs (Vos et al., 1995), which are typically dominant markers based on the selective PCR amplification of small fragments ( 80 to $400 \mathrm{bp}$ ) of genomic DNA, were selected as the primary marker system because they generate a large number of polymorphic bands (i.e., segregating markers), making it possible to develop linkage maps for plants with relative ease and cost effectiveness.

\section{Materials and Methods}

In a previous study, Mwanga et al. (2002) crossed 10 parental (p) sweetpotato clones with varying resistance to SPVD in a modified diallel, disregarding reciprocals, and using the model II, method 4 mating design of Griffing (1956). The work was conducted during 1996-97 at the Namulonge Agricultural and Animal Production Research Institute (NAARI) in Uganda. The mating design yielded a total of 45 families [ $(\mathrm{p}(\mathrm{p}-1) / 2]$. Details of the plant materials, and screenhouse and field experimental designs were described by Mwanga et al. (2002). The two experiments described herein were conducted to further quantify the genetic basis of resistance to SPVD in these progenies. The first experiment consisted of a test of 15 promising diallel progenies for resistance to SPVD at NAARI. The second consisted of a test for resistance to SPCSV and SPFMV, the component viruses of SPVD, and it was conducted at the International Potato Center (CIP), Lima, Peru.

INHERIT ANCE OF RESISTANCE TO SPVDIN PROMISING DIALLEL PROGENIES. To generate information on possible modes of inheritance (Kumagai et al., 1990; Jones, 1967) of resistance to SPVD, 15 


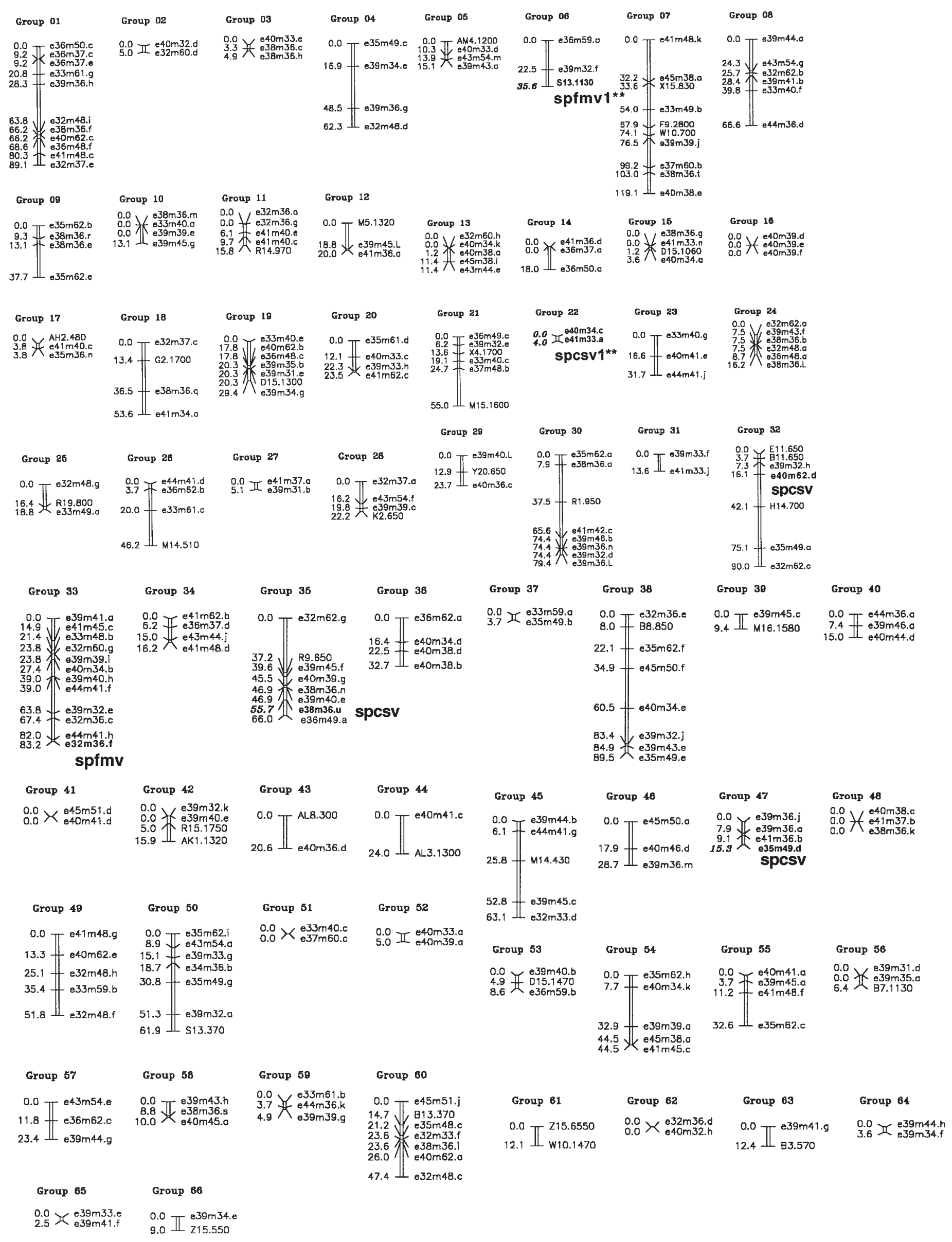


Fig. 1. Sweetpotato maternal ('Tanzania') linkage map based on AFLP and RAPD markers. Cumulative map distances (on left) are in cM. AFLP markers are denoted in the format exx.mxx.x. All other markers are RAPD markers. Each marker locus represents the individual fragments amplified by the same primer combination. Markers associated with resistance to sweetpotato chlorotic stunt virus (SPCSV) on linkage groups 22, 32, 35, and 47, and sweetpotato feathery mottle virus (SPFMV) on linkage groups 6 and 33 are in bold.

promising $\mathrm{F}_{1}$ families from the 45 family diallel crosses evaluated during 1998-2000 (Mwanga et al., 2002) were selected for further study. Each progeny had a large number of individuals, up to 130 genotypes per family (1352 genotypes in total). The plants were grown in 2-L perforated plastic buckets in the screenhouse using previously described methods (Mwanga et al., 2002). Three plants per genotype were graft-inoculated with SPVD at 1.5 months after planting. SPVD severity was scored at 1.5, 2.5, and 3.5 months after inoculation using a 1 to 5 scale, where $1=$ symptomless and $5=$ most severe symptoms (vein clearing, chlorosis, puckering, stunting, tip-dieback) (Mwanga et al., 2002). The experiment was conducted during August to December 1998 and repeated during October 1999 to February 2000.

INHERITANCE OF RESISTANCE TO SPCSV, SPFMV AND SPVD PREDICTED BY EXPECTED THEORETICAL RATIOS. To eXamine resistance to SPCSV and SPFMV individually and in dual graft infection, and formulate hypotheses on the genetic basis of resistance based on expected segregation ratios of resistance to these viruses (Table 1), two crosses between African landrace sweetpotatoes with resistance to SPVD were generated. Family 1 (198 genotypes) consisted of a cross between 'Tanzania' (TAN) $\mathrm{x}$ 'Bikilamaliya' (BMA), while family 2 (87 genotypes) consisted of a cross between TAN x 'Wagabolige' (WAG). Seed from each cross were sent to CIP, and grown in screenhouses between May and December 2000. Each of the genotypes in the two families was propagated to furnish nine plants for three $1.1 \mathrm{~L}$ plastic pots (3 plants per pot).

All mother plants of the two families were tested for SPFMV, SPCSV, sweetpotato mild mottle virus (SPMMV), sweetpotato latent virus (SwPLV), sweetpotato chlorotic flecks virus (SPCFV), sweetpotato mild speckling virus (SPMSV), C-6 virus, and sweetpotato caulimovirus (SPCaLV) using nitrocellulose membrane enzyme-linked immunosorbent assay (NCM-ELISA) kits developed by CIP and North Carolina State University, Raleigh, N.C. (CIP, 1990). In NCM-ELISA, a sample was considered positive when a bluish-purple color developed on the test spot, and control spots from virus-free sweetpotato retained the color of the membrane without changing after 60 min of reaction with the substrate. Plants testing negative were propagated to furnish cuttings for experimental plants of each genotype.

To generate inoculum of SPFMV and SPCSV for the tests the following protocols were followed. The russet crack strain of SPFMV (RC-SPFMV) was obtained from the Virology Laboratory at CIP and used to infect Ipomoea setosa Ker or I. nil cv. Scarlett O'Hara seedlings using techniques described by CadenaHinojosa and Campbell (1981). Cotyledons of I. setosa seedlings were mechanically inoculated with SPFMV at the one- or twoleaf stage. The seedlings were covered with moistened polythene bags for $3 \mathrm{~d}$ after inoculation, and then the bags were removed to allow symptoms of SPFMV to develop. About 400 I. nil seedlings were mechanically inoculated to supply additional SPFMVsymptomatic scions for the experiments conducted on the two families at CIP using this procedure. Inoculum of SPCSV was also maintained in I. setosa (setosa 4) at CIP like SPFMV. However, because SPCSV cannot be transmitted mechanically
(Cohen et al., 1992), inoculum was increased by graft inoculating $\approx 600$ I. setosa seedlings with SPCSV-infected scions of I. setosa. Also, because SPCSV can be symptomless in I. setosa, a subsample of the SPCSV-infected plants was tested by ELISA to ensure that SPCSV was present in the grafting materials. To induce SPVD, I. setosa seedlings with established SPCSV scions were grafted with SPFMV-symptomatic I. setosa or I. nil scions about one week after they were inoculated with SPCSV.

The sweetpotato plants in the three pots ( 3 plants per pot) were treated as follows: 1) each plant in pot number one was graft inoculated with a SPFMV-symptomatic I. setosa or I. nil scion; 2) each plant in pot number two was grafted with a SPCSVsymptomatic I. setosa scion; and 3) each plant in pot number three was grafted with a SPFMV-symptomatic I. nil or I. setosa scion and a SPCSV-symptomatic I. setosa scion to induce SPVD. SPFMV was detected using NCM-ELISA, while SPCSV was detected using TAS-ELISA as previously described (Mwanga et al., 2002). Optical density (OD) values greater than two times the value of control samples were considered positive in for both ELISA tests. Three leaves (one per plant) were sampled per genotype. Shoots from plants testing negative in ELISA assays 3 to 4 weeks after inoculation were grafted on I. setosa plants to confirm negative readings (i.e., that the plants tested were not infected by SPCSV and/or SPFMV). The indicator plants were observed for symptom development for 2 months. Presence of virus in $I$. setosa scions of symptomless graft inoculated plants was confirmed and tested by ELISA.

MoleCUlaR GENETIC ANALYSIS OF RESISTANCE TO SPCSV, SPFMV AND SPVD. The $\mathrm{F}_{1}$-mapping population used to construct the AFLP map for this work was produced from a two-way pseudo-testcross of TAN $\times$ WAG in Uganda. Both parents of this cross are resistant to SPVD, but WAG is more resistant to SPVD than TAN under field SPVD inoculum pressure (Mwanga et al., 2002). True seed from this cross was sent to CIP for AFLP and RAPD genotyping, and SPCSV, SPFMV and SPVD phenotyping. Details of the methods used for DNA extraction, AFLP and RAPD reactions, primer combinations selection, marker nomenclature, marker scoring, estimation of recombination fractions, linkage mapping, and genome coverage and segregation ratios are described by Kriegner et al. (2001). AFLP and RAPD markers present in one parent and absent in the other were tested for 1:1 segregation ratio (presence:absence) in the progeny by a goodness-of-fit $\chi^{2}$ test $(\leq 0.05)$. This single-dose fragment (SDF) mapping strategy, described by Wu et al. (1992), has been widely used for developing genetic maps of polyploid species, such as sugarcane (Saccharum spontaneum L.) (Al Janabi et al., 1993; Da Silva et al. 1995; Ripol et al., 1999), potato (Solanum tuberosum L.) (Li et al., 1998), and alfalfa (Medicago sativus L.) (Yu and Paulus, 1993). The SDF mapping strategy is based on a simplex segregation pattern. In polyploids and outbreeding tree species, this mapping strategy employs the analysis of progeny of a cross between two unrelated heterozygous parents, with the cross being referred to as a two-way pseudo-testcross (Grattapaglia and Sederoff, 1994). Linkage analysis of SDFs in coupling phase with markers placed on the mapping population results in two separate maps, one for each parent based on the male and female sources of markers.

The parental clones TAN and WAG were screened with 82 EcoRI/MseI primer combinations. The combinations resulting in a high number of polymorphic bands were used to genotype the mapping population. For the female parent (TAN) a total of 460 high quality polymorphic fragments were scored, with 330 markers segregating in a 1:1 ratio. Each of these bands was given a 
locus name corresponding to the selective base and a number or letter specific for the individual fragment amplified. For the male parent (WAG) 420 polymorphic marker bands were identified, of which 252 segregated in a 1:1 ratio. The male markers were, however, excluded from the present analysis because the total number of simplex markers was too small to provide adequate coverage of the sweetpotato genome.

Analysis of linkage relationships among markers and map construction was performed using MAPMAKER/EXP/version 3.0 software (Lander et al., 1987). A maximum detectable recombination fraction of $r=0.25$ with a minimum of odds (LOD) score of 4.0 were used to group loci. This procedure placed 271 AFLP and RAPD markers derived from segregation in TAN into 66 linkage groups (Fig. 1). A total of 59 markers remained unlinked under the high LOD score. A high LOD score was used to avoid false linkage detection. This linkage map, which is currently incomplete, but suitable for our preliminary gene-tagging efforts spanned $1860 \mathrm{cM}$ with an average of four AFLP markers per linkage group and an average length of $28 \mathrm{cM}$ per group.

The linkage map constructed from the 271 linked markers was combined with the virus phenotypic data and entered into QGENE (Nelson, 1997) to conduct the QTL analyses. Phenotypic data for SPCSV, SPFMV, and SPVD (SPCSV and SPFMV) scores were coded as a one (1) for positive virus infection or zero (0) for negative results based on the results of ELISA tests described above. Using QGENE, the relation between phenotype (virus resistance) and marker genotype was investigated using the single-point ANOVA and multiple-regression analyses with two markers in the model. Interval analysis was not used because it requires a reliable genetic map (Nelson, 1997) and the current sweetpotato genetic linkage map is not complete.

\section{Results}

INHERITANCE OF RESISTANCE TOSPVDIN PROMISING DIALLEL PROGENIES. Graft inoculation of the 15 families in Uganda resulted in severe SPVD, with no clones being placed in class 1 (symptomless, highly resistant) (Table 2). Only 4 families, WAG x BMA,
WAG $\times$ KAN, WAG $x$ SOW, and TAN x BMA, had more than one clone with a SPVD severity rating of 2 . Highly susceptible genotypes occurred at high frequencies. For example, $85 \%$ of the clones were rated as a 4 or 5 among the families. In contrast, highly resistant genotypes occurred at much lower frequencies $(<1 \%$, class 2$)$. In all the families, the observed distribution of resistant to susceptible genotypes was skewed towards the highly susceptible categories (classes 4 and 5).

INHERITANCE OF RESISTANCE TO SPCSV, SPFMV AND SPVD PREDICTED BY EXPECTED THEORETICAL RATIOS. The eXpected segregation ratios and the results of the SPCSV and SPFMV resistance evaluations are presented in Tables 1 and 3, respectively. Based on serological tests, the TAN x BMA progeny was classified as 89 resistant: 109 susceptible to SPCSV, and 39 resistant: 159 susceptible to SPFMV. The TAN x WAG progenies were classified as 42 resistant: 45 susceptible to SPCSV, and 50 resistant: 37 susceptible to SPFMV, respectively. Segregation analysis of resistance to SPCSV showed that the ratios of resistant to susceptible progenies in family TAN $x$ BMA fit a 1:1 Mendelian ratio $\left(\chi^{2}=2.02, p=0.156\right)$, while the TAN $\times$ WAG family observed segregation ratios (OSRs) fit $1: 1$ ratios, respectively $\left(\chi^{2}=0.10, p\right.$ $=0.335)$. For inheritance of resistance to SPFMV, the OSR in family TAN $x$ WAG fit a $1: 1$ ratio $\left(\chi^{2}=1.94, p=0.099\right.$, whereas in family TAN $x$ BMA, the OSRs fit 3:1, 4:1 and 5:1 ratios $\left(\chi^{2}=\right.$ $\left.2.97, P=0.084 ; \chi^{2}=0.01, p=0.092 ; \chi^{2}=1.31, p=0.253\right)$, respectively.

Graft inoculating the two families (TAN x BMA and TAN $x$ WAG) with SPCSV and SPFMV to induce SPVD at CIP resulted in severe SPVD in all the genotypes except two. Repeated graft inoculations of these two genotypes resulted in severe SPVD in all the genotypes similar to results obtained in Uganda.

MOLECULAR GENETIC ANALYSIS OF RESISTANCE TO SPCSV,SPFMV, AND SPVD. Kriegner et al. (2001) provide a more detailed description of the AFLP-based map constructed from these progenies. The QTL analyses for this work were based on a preliminary map spanning 66 linkage groups with an average distance of $28 \mathrm{cM}$ per group (Fig. 1). Table 4 shows the results of single-marker linear regression analysis for association of AFLP markers with virus

Table 2. Frequency distribution of sweetpotato virus disease (SPVD) severity scores among promising families generated in a diallel cross (SPVD rating, 1 = no symptoms; 5 = very severe symptoms). Tests were conducted at Namulonge, Uganda, 1999-2000.

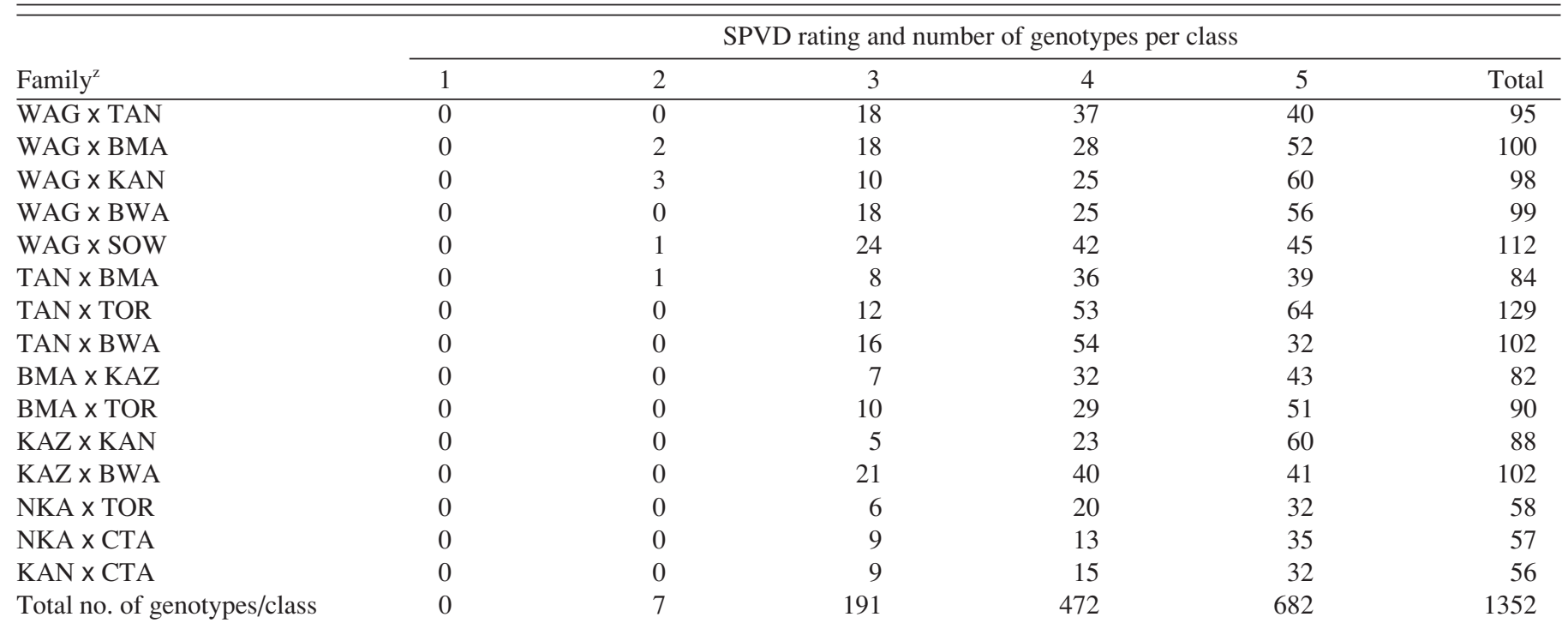

'Cultivar names: 'Bikila Maliya' (BMA); 'Bwanjule' (BWA); 'Camote Tallo' (CTA); 'Kanziga 1' (KAN); 'Kanziga' 2 (KAZ); 'New Kawogo' (NKA); 'Sowola' (SOW); ‘Tanzania' (TAN); ‘Tororo 3' (TOR); and 'Wagabolige' (WAG). 
resistance in the TAN $x$ WAG population. Based on single point regression analyses, two AFLP markers, e41m33.a, and e38m36.u located on linkage groups 22 and 35, respectively, were highly significant $(p<0.0001)$. Minor QTL linked to SPCSV resistance that explained greater than $10 \%$ of the variation in resistance include markers e35m49.d $(p=0.0009)$ and e40m62.d $(p=$ 0.0023 ) on linkage groups 47 and 32, respectively. For resistance to SPFMV, RAPD marker, S13.1130 located on linkage group 6 was highly significant $(p<0.0001)$ explaining $72 \%$ of the variation in resistance. In addition, QTL located near markers e $32 \mathrm{~m} 36 . f$ and e33m59.a on linkage groups 33 and 37, respectively each accounted for $10 \%$ and $9 \%$ of the variation in resistance to SPFMV (Table 4). Addition of a second locus did not significantly increase the percent variation explained by the multiple regression model for resistance to SPCSV or SPFMV, indicating the importance of $e 41 \mathrm{~m} 33 . a$ and S13.1130. Two markers, e38m36.u and e $38 \mathrm{~m} 49$.a, located on linkage group 35 were associated with resistance to SPCSV and SPFMV, but the QTL for SPFMV ( $p=0.01)$ localized near these loci only explained $8 \%$ of the variance (Table 4).

No major QTL were observed for resistance to SPVD when the TAN x WAG sibs were infected by SPCSV and SPFMV to induce SPVD, and, the correlations between AFLP markers and SPVD resistance were relatively low (Table 4).

\section{Discussion}

To date, we know relatively little about the genomic organization of sweetpotato. Cytological studies suggest that sweetpotato has three subgenomes and that two of them are very similar (Jones, 1965; Shiotani and Kawase, 1987; Ting and Kehr, 1953). Chromosome pairing in sweetpotato is as bivalents with very few quadrivalents. Assuming no double reduction, predominantly hexasomic ratios would indicate that all three genomes are similar, whereas predominantly disomic ratios would suggest that the three genomes are distinct. Jones (1967) indicated that the prevalence of tetrasomic or tetradisomic ratios would support the hypothesis of two similar and one different genome proposed by Shiotani and Kawase (1978). Jones (1967) proposed four possible models (with dosage effects) of inheritance (hexasomic, tetradisomic, tetrasomic, and disomic) of one or more genes for sweetpotato (Table 1). In the present study, disomic segregation was ruled out because we did not observe any linkage in the repulsion phase when we tested the pairwise linkage among original and inverted markers (LOD $=4$ and a maximum recombination fraction of 0.4) (Kriegner et al., 2001). As suggested by Wu et al. (1992), this can be used to exclude the hypothesis that cultivated sweetpotatoes arose as an allopolyploid because in disomic polyploids (allopolyploids) repulsion phase linkages should be easily detected. We also excluded testing for segregation ratios for quadruplex inheritance, because they require very large populations for verification, and our populations were small (198 genotypes for TAN x BMA, 87 genotypes for TAN x WAG).

Graft inoculation of progenies with SPVD resulted in severe SPVD in almost all clones of the 15 promising diallel families in Uganda (1352 genotypes). The distribution of SPVD scores in the populations was skewed towards the highly susceptible category (score 5) and very few highly resistant genotypes were observed (score 1 and 2). Similarly, when TAN x BMA and TAN x WAG were graft inoculated with SPCSV and SPFMV to induce SPVD at CIP, severe SPVD was expressed in most of the 285 genotypes tested. The segregation ratios observed in the TAN $\times$ BMA and TAN x WAG families were similar to other traits (e.g., flowering vs nonflowering, red stems vs green stems, storage roots vs no storage roots) studied by Poole (1955), and the presence vs absence of $\beta$-amylase activity in storage roots observed by Kumagai et al. (1990).

Chi-square analyses of the observed vs expected phenotypic data for the TAN $\times$ BMA and TAN $\times$ WAG families for resistance to SPCSV and SPFMV predict that resistance to these viruses is controlled by two separate recessive genes. The expected genetic segregation ratios used for the chi-square analyses were based on the assumption of random chromosome segregation, because the occurrence of primary bivalent pairing with limited tetravalents at meiosis allows the assumption of double reduction (Jones, 1967). Although Jones' (1967) models for major gene inheritance were based on testcrosses, tests conducted by Poole (1955) and Kumagai et al. (1990) included testcrosses and other types of crosses (e.g., open pollination and single crosses) similar to the crosses used in the current study. Therefore, interpreting the

Table 3. Segregation of two sweetpotato families for resistance to sweetpotato chlorotic stunt virus (SPCSV) and sweetpotato feathery mottle virus (SPFMV), International Potato Center (CIP), Lima, Peru, 2000. Negative results indicate that virus was not detected using ELISA and subsequent grafting on I. setosa indicator plants.

\begin{tabular}{|c|c|c|c|c|c|c|c|}
\hline & \multirow[b]{2}{*}{ Virus } & \multicolumn{2}{|c|}{ Genotypes (no.) } & & & & \\
\hline Family & & $\begin{array}{l}\text { Negative } \\
\text { (resistant) }\end{array}$ & $\begin{array}{c}\text { Positive } \\
\text { (susceptible) }\end{array}$ & $\begin{array}{l}\text { Ratio } \\
\text { tested }\end{array}$ & $\chi^{2}$ & $\begin{array}{l}\text { Ratio } \\
\text { tested }\end{array}$ & $\chi^{2}$ \\
\hline \multirow[t]{4}{*}{ TAN x BMA } & SPCSV & 89 & 109 & $1: 1$ & 2.02 & $1: 1$ & 2.02 \\
\hline & & & & & & 3.1 & $34.35^{* * *}$ \\
\hline & SPFMV & 39 & 159 & $1: 1$ & $72.73^{* *}$ & $1: 1$ & $72.73^{* *}$ \\
\hline & & & & & & $11: 1$ & $33.47^{* * *}$ \\
\hline \multirow[t]{4}{*}{ TAN $\times$ WAG } & SPCSV & 42 & 45 & $1: 1$ & 0.10 & $1: 1$ & 0.10 \\
\hline & & & & $4: 1$ & $54.72^{* *}$ & $3: 1$ & $31.44^{* * *}$ \\
\hline & & & & & & $5: 1$ & $76.98^{* *}$ \\
\hline & & & & & & $11: 1$ & $214.43^{* * *}$ \\
\hline
\end{tabular}

\footnotetext{
,** Significant deviation from ratio tested at $P=0.05$ or 0.01 , respectively.
} 
results obtained in this study by Jones' (1967) inheritance models (Table 1) is valid, pending validation by testcrosses and further molecular investigations.

According to the four models of inheritance in sweetpotato (hexasomic, tetradisomic, tetrasomic, disomic) proposed by Jones (1967) and elucidated by Kumagai et al. (1990), SPCSV resistance in this study followed a simplex hexasomic and simplex tetradisomic/tetrasomic model of inheritance in the TAN $x$ BMA and TAN $x$ WAG families. The inheritance of SPFMV exhibited duplex hexasomic and tetradisomic/tetrasomic inheritance pattern in family TAN x BMA, while it followed a simplex hexasomic and simplex tetradisomic/tetrasomic pattern in family TAN $x$ WAG (Tables 1 and 3).

Dominance effects for SPCSV and SPFMV resistance genes were ruled out because all resistant genotypes would have at least one dominant allele. That would mean that at least $50 \%$ of all progenies derived from the resistant parent would be resistant regardless of the model of inheritance (disomic, tetrasomic, tetradisomic, hexasomic). The frequency of genotypes resistant to SPCSV in TAN x BMA was $45.0 \%$ and to SPFMV was $19.7 \%$, while the frequency of genotypes resistant to SPCSV in TAN $x$ WAG was $51.1 \%$ and to SPFMV $41.5 \%$.

The exact allelic frequencies or dosage effects could not be estimated in this study. The allelic composition and allelic diversity of a particular genotype may be revealed by molecular techniques and studies on segregation of identified major genes. Although our data suggest that the frequency of resistant SPFMV and SPCSV alleles is high, the resistant phenotypes are not as common due to the polysomic nature of sweetpotato and the traits being recessive.

There are many examples of virus resistance being conditioned by recessive genes in plants. Resistance to bean yellow mosaic virus (BYMV) in the bean cultivar, Great Northern 1140, is conditioned by a single recessive gene (Provvidenti and Schroeder, 1973). In barley, resistance to barley yellow dwarf virus (BYDV) may be conditioned by dominant or recessive genes depending on environmental conditions (Jones and Catherall, 1970). In pepper, Capsicum chinense Jacq. (PI 159236), resistance to a pepper strain of potato virus Y (PVY pathotype 12 ) is controlled by a major recessive gene (Boiteux et al., 1996). Fraser (1986) gives more examples of recessive resistance genes for plant viruses. Further, some recessive genes may completely suppress virus multiplication conferring immunity (Provvidenti and Schroeder, 1973), while others may confer resistance in a similar manner to those for resistance to SPCSV and SPFMV by reducing symptom severity and virus multiplication, but maintaining virus levels that can still be detected (Catherall et al., 1970).

It has been previously demonstrated that resistance to SPFMV and SPCSV breaks down when the two viruses coinfect the same plant resulting in severe SPVD symptoms (Karyeija et al., 2000; Mwanga et al., 2002; Schaefers and Terry, 1976). The loss of resistance is expressed as occurrence of SPFMV symptoms and high absorbance values, indicating high SPFMV and/or SPCSV titers in the plant, eliminating the resistant category. Highly susceptible sweetpotato cultivars infected with only SPFMV suffer significant yield losses (Clark and Moyer, 1988). But economic losses due to SPFMV are more commonly associated with external cracking and internal corkiness, which render storage roots unmarketable. In contrast, yield losses due to SPCSV are quite high with up to $87 \%$ loss in storage root yield being reported in screenhouse experiments (Gibson et al., 1998).

Based on our preliminary AFLP mapping studies, SPCSV resistance was associated with AFLP markers e4lm33.a and

Table 4. AFLP and RAPD markers associated with $\geq 10 \%$ resistance to sweetpotato chlorotic stunt virus (SPCSV) and sweetpotato feathery mottle virus (SPFMV), and $\geq 5 \%$ of the variability in resistance to sweetpotato virus disease (SPVD) in the 'Tanzania' $\mathrm{x}$ 'Wagabolige' cross. S13.1130 is a RAPD marker, all others are AFLP markers.

\begin{tabular}{|c|c|c|c|c|c|}
\hline Marker & $\begin{array}{l}\text { Linkage } \\
\text { group }\end{array}$ & $\begin{array}{c}\text { No. of } \\
\text { genotypes (n) }\end{array}$ & $\mathrm{F}$ & $R^{2}$ & $P$ \\
\hline \multicolumn{6}{|l|}{$\overline{\text { SPCSV }}$} \\
\hline e41m33.a & 22 & 85 & 195.09 & 0.70 & 0.0000 \\
\hline e38m36.u & 35 & 87 & 19.24 & 0.19 & 0.0000 \\
\hline e36m49.a & 35 & 86 & 13.63 & 0.14 & 0.0004 \\
\hline e39m45.f & 35 & 86 & 10.06 & 0.11 & 0.0021 \\
\hline e40m62.d & 32 & 86 & 9.91 & 0.11 & 0.0023 \\
\hline e39m36.a & 47 & 87 & 9.23 & 0.10 & 0.0032 \\
\hline \multicolumn{6}{|l|}{ SPFMV } \\
\hline $\mathrm{S} 13.1130$ & 6 & 84 & 205.83 & 0.72 & 0.0000 \\
\hline e39m32.f & 6 & 80 & 41.02 & 0.35 & 0.0000 \\
\hline $\mathrm{e} 35 \mathrm{~m} 49 . \mathrm{c}$ & 4 & 86 & 4.43 & 0.05 & 0.0383 \\
\hline e $32 \mathrm{~m} 48 . \mathrm{a}$ & 24 & 86 & 4.22 & 0.05 & 0.0431 \\
\hline e $38 \mathrm{~m} 36 . \mathrm{b}$ & 24 & 87 & 4.10 & 0.05 & 0.0460 \\
\hline e39m43.f & 24 & 87 & 4.10 & 0.05 & 0.0460 \\
\hline e41m37.a & 27 & 87 & 4.10 & 0.05 & 0.0460 \\
\hline e35m49.a & 32 & 84 & 4.04 & 0.05 & 0.0477 \\
\hline
\end{tabular}


e38m36.u on linkage groups 22 and 35, respectively. Marker e41m33. $a$ explained $70 \%$ of the variation in SPCSV resistance in single-marker regression analysis. Because marker e4lm33.a explained such a high percentage of the variation in SPCSV resistance we speculate that this marker is linked to a major recessive gene for resistance to SPCSV. We propose the name, spcsvl (sweetpotato chlorotic stunt virus 1), for the gene mediating SPCSV resistance.

SPFMV resistance was associated with several markers, but S13.1130 was by far the strongest QTL explaining $72 \%$ of the resistance to SPFMV. Because marker S13.1130 explained such a high percentage of resistance to SPFMV, it is also likely associated with another major recessive gene. Thus we propose the name spfmvl (sweetpotato feathery mottle virus 1) for the gene mediating resistance for SPFMV.

The QTL analyses support our hypothesis that resistance to SPCSV and SPFMV in TAN $x$ WAG and TAN $x$ BMA is governed by two separate major genes. The additional QTL associated with SPCSV and SPFMV resistance suggest that there may also be one or more minor genes associated with resistance to these viruses. Further, it is possible that some QTL (e.g., marker e38m36.u on linkage group 35) may be associated with resistance to both viruses. These studies represent the first quantitative and molecular genetic investigations of the inheritance of resistance to SPCSV, SPFMV, and SPVD. Results from this work should provide impetus for more investigations using DNA markers for genetic studies of these important viruses and lead to improvements in breeding for resistance to SPCSV, SPFMV, and SPVD in sweetpotato. However, additional tests will be necessary to 1) confirm that SPCSV and SPFMV are indeed governed by two major genes; 2) determine if the two genes present in a common background will suppress SPVD effectively; 3) establish if there are other genes conditioning resistance to SPVD and determine their nature, and 4) determine the exact allelic composition and allelic diversity of the genes conditioning SPVD resistance using molecular techniques and additional inheritance studies.

\section{Literature Cited}

Al-Janabi, S.M., R.J. Honeycutt, M. McClelland, and B.W.S. Sobral. 1993. A genetic linkage map of Saccharum spontaneum (L.) 'SES 208'. Genetics 134:1249-1260.

Barone, A., E. Ritter, U. Schachtschabel, T. Debener, F. Salamini, and C. Gebhardt. 1990. Localization by restriction fragment length polymorphism mapping in potato of a major dominant gene conferring resistance to the potato cyst nematode Globodera rostochiensis. Mol. Gen. Genet. 224:177-182.

Bendahmane, A., K. Kanyuka, and D.C. Baulcombe. 1997. Highresolution genetical and physical mapping of the $R x$ gene for extreme resistance to potato virus X in tetraploid potato. Theor. Appl. Genet. 95:153-162.

Boiteux, L.S., F.P. Cupertino, C. Silver, A.N. Dusi, and D.C.M. Neshich. 1996. Resistance to potato virus Y (pathotype 1-2) in Capsicum annuum and Capsicum chinense is controlled by two independent major genes. Euphytica 87:53-58.

Bradshaw, J.E., C. A. Hackett, R.C. Meyer, D. Milbourne, J.W. McNicol, M.S. Philips, and R. Waugh. 1998. Identification of AFLP and SSR markers associated with quantitative resistance to Globodera pallida (Stone) in tetraploid potato (Solanum tuberosum subsp. tuberosum) with a view to marker-assisted selection. Theor. Appl. Genet. 95:153162.

Cadena-Hinojosa, M.A. and R.N. Campbell. 1981. Characterization of isolates of four aphid-transmitted sweetpotato viruses. Phytopathology 71:1086-1089.
Catherall, P.L., A.T. Jones, and J.D. Hayes. 1970. Inheritance of genes in barley that condition tolerance to barley yellow dwarf virus. Ann. Appl. Biol. 65:153-161.

CIP. 1990. Annual report. Intl. Potato Center, Lima, Peru.

Clark, C.A. and J.W. Moyer. 1988. Compendium of sweetpotato diseases. APS Press, Amer. Phytopathol. Soc., St. Paul, Minn.

Cohen, J., A. Frank, H.J. Vetten, D.E. Lesemann, and G. Loebestein. 1992. Purification and properties of closterovirus-like particles associated with a whitefly transmitted disease of sweetpotato. Ann. Appl. Biol. 121:257-268.

Da Silva J.A.G., R.J. Honeycutt, W. Burnquist, S.M.Al-Janabi, M.E. Sorrels, S.D. Tanksley, and B.W.S. Sobral. 1995. Saccharyn spontaneum L. SES 208 genetic linkage map combining RFLP- and PCR-based markers. Mol. Breeding 1:165-179.

De Jong, W., A. Forsyth, D. Leister, C. Gebhardt, and D.C. Baulcombe. 1997. A potato hypersensitive resistance gene against potato virus X maps to a resistance gene cluster on chromosome 5. Theor. Appl. Genet. 95:246-252.

Food and Agricultural Organization of the United Nations. 2000. FAO statistics. In: http://apps.fao.org-Food and Agricultural Organization of the United Nations, Rome, Italy.

Food and Nutrition Board. 1980. Recommended daily allowances. Natl. Acad. Sci., Natl. Research Council, Wash., D.C.

Fraser, R.S.S. 1986. Genes for resistance to plant viruses. CRC Crit. Rev. Plant Sci. 3:257-294.

Gibson, R.W., I. Mpembe, T. Alicai, E.E. Carey, R.O.M. Mwanga, S.E. Seal, and H.J. Vetten. 1998. Symptoms, aetiology and serological analysis of sweetpotato virus disease in Uganda. Plant Pathol. 47:95102.

Grattapaglia, D. and R. Sederoff. 1994. Genetic linkage of maps of Eucalyptus grandis and Eucalyptus urophylla using pseudo-testcross: Mapping strategy and RAPD markers. Genetics 137:1121-1137.

Gregory, P.M., M. Iwanaga, and D.E. Horton. 1990. Sweetpotato: Global issues, p. 462-468. In: R.H. Howeler (ed.). Proc. 8th Symp. Intl. Soc. Trop. Root Crops, CIAT, Bangkok, Thailand.

Griffing, B. 1956. Concept of general and specific combining ability in relation to diallel crossing systems. Austral. J. Biol. Sci. 9:463-493.

Hahn, S.K., E.R. Terry, and K. Leuschner. 1981. Resistance of sweetpotato to virus complex. HortScience 16:535-537.

Horton, D.E. 1988. World patterns and trends in sweetpotato production. Trop. Agr. 65:268-270.

Hoyer, U., E. Maiss, W. Jelkman, D.E. Lesemann, and J.H. Vetten. 1996. Identification of the coat protein gene of a sweetpotato sunken vein closterovirus isolate from Kenya and evidence for a serological relationship among geographically diverse closeterovirus isolates from sweetpotato. Phytopathology 86:744-750.

Jacobs, J.M.E., H.J. Van Eck, P. Arens, B.V. Bakker, B.L. Hekkert, H.J.M. Bastiaanssen, A.E. Kharbotly, A. Pereira, E. Jacobsen, and W.J. Stickema. 1995. A genetic map of potato (Solanum tuberosum) integrating molecular markers, including transposons, and classical markers. Theor. Appl. Genet. 91:289-300.

Jin, H., L.L. Domier, L. Kolb, and C.M. Brown. 1998. Identification of qualitative loci for tolerance to barley yellow dwarf virus in oat. Phytopathology 88:410-415.

Jones, A. 1965. Cytological observations and fertility measurements of sweetpotato [Ipomoea batatas (L.) Lam]. Proc. Amer. Soc. Hort. Sci. 86:527-537.

Jones, A. 1967. Theoretical segregation ratios of qualitatively inherited characters for hexaploid sweetpotato (Ipomoea batatas). USDA Tech. Bul. No. 1368.

Jones, A. 1977. Heritabilities of seven sweet potato root traits. J. Amer. Soc. Hort. Sci. 102:440-442.

Jones, A.J. and P.L. Catherall. 1970. The effect of different virus isolates on the expression of tolerance to barley yellow dwarf virus in barley. Ann. Appl. Biol. 65:147-152.

Jones, A.J., P.D. Dukes, and F.P. Cuthbert, Jr. 1976a. Mass selection in sweet potato: Breeding for resistance to insects and diseases and for horticultural characteristics. J. Amer. Soc. Hort. Sci. 101:701-704. 
Jones, A.J., M.G. Hamilton, and P.D. Dukes. 1976b. Heritability estimates for fiber content, root weight, shape, cracking and sprouting in sweet potato. J. Amer. Soc. Hort. Sci. 103:374-376.

Karyeija, R.F., Gibson, R.W, and J.P.T. Valkonen. 1998. The significance of sweetpotato feathery mottle virus in subsistence sweetpotato production in Africa. Plant Dis. 82:4-15.

Karyeija, R.F., J.F. Kreuze, R.W. Gibson, and J.P.T. Valkonen. 2000. Synergistic interactions of a potyvirus and a phloem-limited crinivirus in sweetpotato plants. Virology 296:26-36.

Kriegner, A., J.C. Cervantes, K. Burg, R.O. Mwanga, and D.P. Zhang. 2001. A genetic linkage map of sweetpotato [Ipomoea batatas (L.) Lam.] based on AFLP markers, p. 303-314. In: Partners in research for the $21^{\text {st }}$ century. Intl. Potato Center Progr. Rpt. 1999-2000.

Kumagai, T., Y. Umemura, T. Baha, and M. Iwanaga. 1990. The inheritance of $\beta$-amylase null in storage roots of sweetpotato, Ipomoea batatas (L.) Lam. Theor. Appl. Genet. 79:369-376.

Lander, E.S., P. Green, J. Abrahamson, A. Barlow, M.J. Daly, S.E. Lincolin, and L. Newburg. 1987. MAPMAKER: An interactive computer package for constructing primary genetic linkage maps of experimental natural populations. Genomics 1:174-181.

Li, X., H.J. van Eck, J.N.A.M. Rouppe van der Voort, D.J. Huigen, P. Stam, and E. Jacobson. 1998. Autotetraploids and genetic mapping using common AFLP markers: The R2 allele conferring resistance to Phytophthora infestans mapped on potato chromosome 4. Theor. Appl. Genet. 96:1121-1128.

Magoon, M.L., R. Krishnan, and K.V. Baii. 1970. Cytological evidence on the origin of sweetpotato. Theor. Appl. Genet. 40:360-366.

Martin, F.W. 1965. Incompatibility in the sweetpotato, a review. Econ. Bot. 19:406-415.

Martin, F.W. 1970. Self and interspecific incompatibility in the convolvulaceae. Bot. Gaz. 131:139-144.

Mwanga, R.O.M., G.C. Yencho, and J.W. Moyer. 2002. Diallel analysis of sweetpotato for resistance to sweetpotato virus disease. Euphytica (in press).

Nakanishi, T. and Kobayashi. M. 1979. Geographic distribution of cross incompatibility group in sweetpotato. Incompatibility Nswlt. 11:72-75.

Nelson, J.C. 1997. QGENE: Software for marker-based genomic analysis and breeding. Mol. Breeding 3:239-245.

Ngeve, J.M. and J.C. Bouwkamp. 1991. Effect of sweetpotato virus disease (SPVD) on the yield of sweetpotato genotypes in Cameroon. Expt. Agr. 27:221-225.

Nissila, E.A.J., V.R. Ramanathat, F. Engelmann, and R.K. Riley. 1999. Ex situ strategies for complementary conservation of Asian sweetpotatoes. Plant Genet. Resources Nswlt. 117:1-11.

Nishiyama, I., T. Miyazaki, and S. Sakamoto. 1975. Evolutionary autoploidy in sweetpotato (Ipomoea batatas (L.) Lam) and its progenitors. Euphytica 24:197-208.
Pongam, P., T.C. Osborn, and P.H. Williams. 1998. Genetic analysis and identification of amplified fragment length polymorphism markers linked to the alml avirulence gene of Leptosphaeria maculans. Phytopathology 88:1068-1072.

Poole, C.F. 1955. Sweetpotato genetic studies. Hawaii Agr. Expt. Sta. Tech. Bul. 27.

Provvidenti, R. and W.T. Schroeder. 1973. Resistance in Phaseolus vulgaris to severe strain of bean yellow mosaic virus. Phytopathology 63:196-197.

Ripol M.I., G.A. Churchill, J.A.G. Da Silva, and M. Sorrels. 1999. Statistical aspects of genetic mapping in autopolyploids. Gene 235:3141.

Schaefers, G.A. and E.R. Terry. 1976. Insect transmission of sweetpotato disease agents in Nigeria. Veinclearing, chlorotic stunt. Phytopathology 66:642-645.

Shiotani, I. 1988. Genomic structure and gene flow in sweetpotato and related species, p. 61-73. In: P. Gregory (ed.). Exploration, maintenance, and utilization of sweetpotato genetic resources, first planning conference. Intl. Potato Center, Lima, Peru.

Shiotani, I. and T. Kawase. 1987. Genomic structure of sweetpotato and hexaploids in Ipomoea trifida (HBK.) Don. Jpn. J. Breeding 39:57-66.

Stubbs, L.L. and D.L. McLean. 1958. A note on aphid transmission of feathery mottle virus of sweetpotato. Plant. Dis. Rpt. 42:216.

Thompson, P.G., J.C. Schneider, and B. Graves. 1994. Genetic variance component and heritability estimates of freedom from weevil injury to sweetpotato. J. Amer. Soc. Hort. Sci. 119:620-623.

Ting, Y.C. and A.E. Kehr. 1953. Meiotic studies in sweetpotato [Ipomoea batatas (L.) Lam]. J. Hered. 44:207-211.

Ukoskit, K. and P.G. Thompson. 1997. Autopolyploidy versus allopolyploidy and low-density randomly amplified polymorphic DNA linkage maps of sweetpotato. J. Amer. Soc. Hort. Sci. 122:822-828.

Vos P., R. Hogers, M. Bleeker, M.Rijans, T. van de Lee, M. Hornes, A. Frijters, J. Peleman, M. Kuiper, and M. Zabeau. 1995. AFLP: A new technique for DNA fingerprinting. Nucleic Acids Res. 23:4407-4414.

Watt, B.K. and A.L. Merrill. 1975. Handbook of the nutritional contents of foods. Dover Publ., Inc., New York.

Wisler, G.C., J.E. Duffus, H.Y. Liu, and R.H. Li. 1998. Ecology and epidemiology of whitefly-transmitted closteroviruses. Plant Dis. 82:270-280.

Woolfe, J.A. 1992. Sweetpotato, an untapped food resource. Cambridge Univ. Press, Cambridge, U.K.

Wu, K.K., W. Burnquist, M.E. Sorrels, T.L. Tew, and S.D. Tanksley. 1992. The detection and estimation of linkage in polyploids using single-dose restriction fragments. Theor. Appl. Genet. 99:294-300.

Yu, K.F. and K. Paulus. 1993. Segregation of random polymorphic DNA markers and strategies for molecular mapping in tetraploid alfalfa. Genome 36:844-856 